\title{
PENGARUH MINAT BERWIRAUSAHA DAN PENGGUNAAN SOSIAL MEDIA TERHADAP KEWIRAUSAHAAN MAHASISWA
}

Oleh:

\author{
Eswanto Sugeng Rahayu'); Siti Laela' ${ }^{2}$ \\ Sekolah Tinggi Ilmu Ekonomi IPWI Jakarta2) \\ eswantosr@gmail.com ${ }^{1)}$; Siti_laela65@yahoo.com ${ }^{2}$
}

\begin{abstract}
ABSTRAK
Penelitian ini bertujuan mengetahui Pengaruh Minat Berwirausaha dan Penggunaan Media Sosial Terhadap Kewirausahaan pada Mahasiswa.

Objek dari penelitian ini adalah mahasiswa Mahasiswa STIE IPWIJA Kampus Cikeas di Bogor pada tahun Ajaran semester genap 2017/2018 dengan jumlah populasi 448. Jumlah sampel diambil dengan rumus Slovin sehingga diperoleh jumlah sampel 84. Data dalam penelitian ini diolah dengan analisis regresi untuk memperoleh tujuan dari penelitian.

Kesimpulan yang diperoleh dalam penelitian ini adalah ada pengaruh minat berwirausaha terhadap kewirausahaan pada Mahasiswa. Ada pengaruh penggunaan media sosial terhadap kewirausahaan pada Mahasiswa.
\end{abstract}

Kata kunci:

Minat Berwirausaha, Penggunaan Sosial Media dan Kewirausahaan

\section{PENDAHULUAN}

Visi STIE IPWIJA sebagaimana yaitu menjadi program studi manajemen yang menginspirasi mahasiswa memiliki kemampuan manajerial dan jiwa kewirausahaan pada tahun 2020

Hal ini berarti ada tujuan kedepan yang harus dicapai yaitu mahasiswa dan alumninya mampu berwirausaha. Hal ini dilakukan dengan memasukan materi dan kuliah yang mengandung muatan kewirausahaan dan bisnis. Selain itu dilakukan beberapa seminar bisnis yang mendukung visi tersebut. Juga dibentuk inkubator dan mengikut sertakan mahasiswa dalam Program Ktreatifitas Mahasiswa
Namun adakah Minat berwirausaha pada mahasiswa IPWIJA. Penelitian awal yang peneliti lakukan menghasilkan bahwa terdapat pengaruh yang signifikan minat berwirausaha terhadap kewirausahaan. Namun dari pengamatan langsung terhadap kegiatan kewirausahaan yang dilakukan oleh kampus, keikutsertaan mahasiswa dikatakan relative sedikit 6-10 \% dibandingkan dengan jumlah mahasiswa.

Abad ini dikenal dengan revolusi indsutri 4.0, dimana siapa yang menguasai informasi, maka akan menguasai dunia. Dan derasnya informasi yang ada di dukung dengan lahirnya alat komunikasi pendukungnya yang dikenal dengan 
smartphone atau Sosial Media. Perkembangan e-commerce Kepala Badan Pusat Statistik (BPS) Suhariyanto mengatakan, dari Sensus Ekonomi 2016 yang dilakukan pihaknya, muncul data sementara jumlah e-commerce yang ada di Indonesia. Dalam kurun waktu 10 tahun, jumlah e-commerce di Indonesia meningkat sekitar 17 persen

Dengan pertumbuhan pengguna internet, Bank Indonesia memperkirakan ada 24,7 juta orang yang berbelanja online. Nilai transaksi e-Commerce diprediksi mencapai Rp 144 triliun pada 2018. Jakarta, CNN Indonesia -- Generasi muda dalam rentang usia 20-24 tahun dan 25-29 tahun memiliki angka penetrasi hingga lebih dari 80 persen pengguna internet di Indonesia. Angka tersebut relatif tinggi ketimbang penduduk kelompok usia lainnya berdasarkan riset terbaru yang dirilis Asosiasi Penyelenggara Jasa Internet Indonesia.

Berisi tentang penjelasan umum sampai dengan khusus berkenaan dengan penelitian yang dilakukan. Dengan membaca bab ini diharapkan pembaca bisa paham konsep yang diusung author, variabel yang muncul, metode yang digunakan, dan kelebihan artikel dibanding yang lain. Oleh karena itu dalam bab ini muncul permasalahan pokok dan turunannya atau dari permasalahan umum ke permasalahan khusus. Dalam bab ini lebih baik apabila didukung adanya gap penelitian yang menjadi celah penelitian yang menjadi keunggulan artikel ini.

Abad ini dikenal dengan revolusi indsutri 4.0, dimana siapa yang menguasai informasi, maka akan menguasai dunia. Dan derasnya informasi yang ada di dukung dengan lahirnya alat komunikasi pendukungnya yang dikenal dengan smartphone atau Sosial Media. Perkembangan e-commerce Kepala Badan Pusat Statistik (BPS) Suhariyanto mengatakan, dari Sensus Ekonomi 2016 yang dilakukan pihaknya, muncul data sementara jumlah e-commerce yang ada di Indonesia. Dalam kurun waktu 10 tahun, jumlah e-commerce di Indonesia meningkat sekitar 17 persen

Dengan pertumbuhan pengguna internet, Bank Indonesia memperkirakan ada 24,7 juta orang yang berbelanja online. Nilai transaksi e-Commerce diprediksi mencapai Rp 144 triliun pada 2018. Jakarta, CNN Indonesia -- Generasi muda dalam rentang usia 20-24 tahun dan 25-29 tahun memiliki angka penetrasi hingga lebih dari 80 persen pengguna internet di Indonesia. Angka tersebut relatif tinggi ketimbang penduduk kelompok usia lainnya berdasarkan riset terbaru yang dirilis Asosiasi Penyelenggara Jasa Internet Indonesia.

Pada kategori 20-24 tahun ditemukan 22,3 juta jiwa yang setara 82 persen dari total penduduk di kelompok itu. Sedangkan pada kelompok 25-29 tahun, terdapat 24 juta pengguna internet atau setara 80 persen total jumlah jiwa. Temuan itu didukung dengan diketahuinya profesi mahasiswa sebagai profesi yang paling banyak menggunakan internet ketimbang sektor lain. Kedua kelompok usia itu meninggalkan jauh kelompok usia lainnya yakni kategori usia 30-34 tahun dan 35-39 tahun. Kedua kelompok ini punya jumlah pengguna internet yang relatif tak jauh beda dengan mereka yang lebih muda di angka 20-an juta. Namun dibanding jumlah penduduknya, pengguna internet di kelompok itu hanya sekitar 72 persen dan 63 persen. Media sosial merajai konten internet sebagai yang paling sering diakses netizen. Tercatat 97,4 persen orang Indonesia mengakses akun media sosial saat mengunakan internet.

Selain itu, indikasi dominasi usia muda terlihat dari aktivitas menonton film secara daring, memutar musik online, dan 
menonton olahraga online menjadi pilihan utama pengguna internet sebagai sumber hiburannya. Cukup jelas ketiga aktivitas itu dekat dengan gaya hidup kelompok usia muda. Gejala demikian dapat dilacak dari produk-produk operator yang menyasar segmen anak muda. Sebut saja Spotify dan Iflix bersama Indosat serta Hooq bersama Telkomsel. Streaming film itu ramai sekali kan. Makanya enggak heran banyak pemain di sektor itu berbondong-bondong masuk ke sini," ujar Henri Kasyfi Soemartono, Sekretaris Jenderal APJII di Jakarta

\section{TUJUAN PENELITIAN}

Tujuan penelitian ini yaitu untuk mengetahui dan menganalisis pengaruh minat berwirausaha dan penggunan media social terhadap kewirausahaan pada Mahasiswa STIE IPWIJA Kampus Cikeas di Bogor.

\section{TELAAH LITERATUR PENGEMBANGAN HIPOTESIS \\ Minat Berwirausaha}

Minat adalah kecenderungan dan keinginan yang besar terhadap sesuatu yang terdiri dari suatu perasaan senang, harapan, perasaan tertarik, yang muncul karena kemauan dan kecendrungankecendrungan yang lain yang mengarahkan seseorang kepada suatu pilihan atau motif.

Menurut Thomas W. Zimmerer dan Norman M. Scarbrough (2007) wirausahawan adalah orang yang menciptakan bisnis baru dengan mengambil risiko dan ketidakpastian demi mencapai keuntungan dan pertumbuhan dengan cara mengidentifikasi peluang dan menggabungkan sumber daya yang diperlukan untuk mendirikannya. Keberaninan mengambil risiko sudah menjadi milik seorang wirausahawan karena ia dituntut untuk berani dan siap jika usaha yang dilakukan tersebut belum memiliki nilai perhatian di pasar, dan ini harus dilihat sebagai bentuk proses menuju wirausahawan sejati (Irham Fahmi, 2013: 1-2).

Menurut Fuadi dalam Rosmiati, Dony T \& Munawar (2015:23) minat berwirausaha adalah keinginan, ketertarikan, serta kesediaan untuk bekerja keras atau berkemauan keras untuk berusaha secara maksimal untuk memnuhi kebutuhan hidupnya tanpa merasa takut dengan risiko yang akan terjadi, serta berkemauan untuk belajar dari kegagalan.

Minat menjadi wirausaha didefinisikan sebagai keinginan seseorang untuk bekerja mandiri (self employed) atau menjalankan usahanya sendiri. Minat wirausaha adalah keinginan, ketertarikan, serta kesediaan untuk bekerja keras atau berkemauan untuk berusaha memenuhi kebutuhan hidupnya tanpa merasa takut akan risiko yang akan dihadapi, belajar dari kegagalan yang dialami, serta mengembangkan usaha yang diciptakannya. Minat berwirausaha dapat dilihat dari ketersediaan untuk bekerja keras dan untuk mencapai kemajuan usahanya, kesediaan menanggung macammacam risiko berkaitan dengan tindakan yang dilakukannya.

Beberapa alasan yang mendorong seseorang tertarik dan berminat untuk membuka usaha sendiri (Jackie Ambadar, dkk, 2010: 32-35).

a. Penghasilan Tidak Terbatas

Banyak orang mengakui ketertarikannya membuka usaha sendiri adalah karena ingin memiliki penghasilan besar.

b. Ingin Cepat Kaya

Untuk mewujudkan semua keinginankeinginan jalan termudah dan sudah diakui kenyataannya adalah dengan 
cara memiliki usaha sendiri. Hanya bekerja keraslah yang akan membuat suatu usaha bisa sukses dan mendatangkan rezeki melimpah. Sebab, mana mungkin bisa hidup mewah tanpa kerja keras dan susah payah.

c. Ingin Mandiri

Dengan tekad yang kuat ingin membuka usaha sendiri, secara tidak langsung hal tersebut menunjukkan sikap mental yang kuat, yaitu sebuah keinginan untuk mandiri.

d. Keadaan Terdesak

Di antara faktor yang menjadi alasan kuat mengapa seseorang ingin membuka usaha sendiri adalah persoalan ekonomi, yaitu ketika mendapati suatu peristiwa seperti Pemutusan Hubungan Kerja (PHK). Sebagai jalan alternatif untuk terus membiayai kehidupan keluarga, maka pilihan tercepat adalah dengan membuka usaha sendiri. Hal itu lebih mudah dilakukan daripada harus berebut mencari pekerjaan baru. Sementara jumlah pencari kerja dan ketersediaan lapangan pekerjaan sekarang ini sudah tidak berimbang.

e. Memperoleh Kebanggaan atau Kepuasan

Apabila usaha yang dilakukan berhasil merupakan sebuah kebanggaan dan kepuasan tersendiri, dengan perasaan senang dan bangga bisa menunjukkan kepada orang lain tentang keberhasilan yang dicapai.

f. Ingin Bebas Mewujudkan Mimpi atau Mengaplikasikan Ide

Tidak semua alasan/ keinginan membuka usaha sendiri semata-mata ingin mencari keuntungan besar. Banyak pengusaha yang sukses mengawali langkah mereka karena keinginannya mewujudkan mimpi memiliki usaha sendiri. Sehingga mereka bisa leluasa mengaplikasikan ide ataupun gagasan kreatifnya.

Minat berwirausaha tidak dibawa sejak lahir tapi tumbuh dan berkembang sesuai dengan faktor-faktor yang mempengaruhi. Faktor yang memengaruhi tumbuhnya keputusan untuk berwirausaha merupakan hasil interaksi dari beberapa faktor yaitu karakter kepribadian seseorang dan lingkungannya (Bygrave, 2003).

Menurut Lambing dan Kuehl (2007), hasil penelitian terbaru menunjukkan ada empat hal yang memengaruhi keputusan berwirausaha, yaitu diri pribadi, lingkungan budaya, kondisi sosial, dan kombinasi dari ketiganya. Sedangkan menurut Hisrich, et al. (2005: 18) dan Alma (2010: 12), faktor yang memengaruhi minat wirusaha adalah lingkungan pendidikan, kepribadian seseorang dan lingkungan keluarga.

Minat berwirausaha seseorang dapat dilihat dari dua indikator utama yaitu :

1. seberapa kuat upaya seseorang untuk berani mencoba melakukan aktivitas kewirausahaan;

2. seberapa banyak upaya yang direncanakan seseorang untuk melakukan aktivitas kewirausahaan (seperti aktivitas dalam mengelola waktu dan keuangan untuk tujuan berwirausaha).

Untuk mendorong tumbuhnya minat terhadap kegiatan dunia usaha yaitu dengan cara mengenali potensi yang ada pada diri akan membantu langkah kita untuk menjalankan usaha menjadi lebih baik lagi. Dalam kondisi perekonomian yang tidak stabil, terjadi krisis yang berkepanjangan, semakin sedikitnya lowongan dan lapangan pekerjaan. Dengan adanya hal tersebut dapat diupayakan untuk tumbuhnya minat wirausaha masyarakat, terlebih adanya ajakan dan dorongan untuk melakukan 
kegiatan mandiri dalam bentuk wirausaha. Melalui kegiatan wirausaha akan menciptakan daya tarik tersendiri bagi pemiliknya, daya tarik itu berupa keuntungan milik pribadi, kebebasan melakukan usaha, dan punya kepuasan tersendiri atas prestasi atau hasil yang diperoleh dari usaha sendiri (A. Jalaludin Sayuti, 2015:185)

\section{Penggunaan Media Sosial}

Media sosial menurut Philip Kotler dan Kevin Keller (2012: 568), merupakan sarana bagi konsumen untuk berbagi informasi teks, gambar, audio, dan video dengan satu sama lain dan dengan perusahaan dan sebaliknya. Peran media sosial semakin diakui dalam mendongkrak kinerja bisnis. Media sosial memungkinkan bisnis kecil dapat mengubah cara berkomunikasi dengan pelanggan, memasarkan produk dan jasa serta saling berinteraksi dengan pelanggan yang bertujuan untuk membangun hubungan yang baik.

Pendapat lain diungkapkan oleh Shirky dalam Rulli Nasrullah (2016: 11), media sosial dan perangkat lunak sosial merupakan alat untuk meningkatkan kemampuan pengguna untuk berbagi (to share), bekerja sama (to co-operate) diantara pengguna dan melakukan tindakan secara kolektif yang semuanya berada diluar kerangka institusional maupun organisasi. Sedangkan menurut Boyd dalam Rulli Nasrullah (2016:11), menjelaskan media sosial sebagai kumpulan perangkat lunak yang memungkinan individu maupun komunitas untuk berkumpul, berbagi, berkomunikasi, dan dalam kasus tertentusaling berkolaborasi atau bermain.

Menurut Puntoadi dalam Viny Putri Fauzi (2016) penggunaan atau pemanfaatan media sosial sebagai berikut :
1) Keunggulan membangun personal branding melalui social media adalah tidak mengenal trik atau popularitas semu, karena audiens lah yang akan menentukan. Berbagai media sosial dapat menjadi media untuk orang berkomunikasi, berdiskusi, bahkan mendapatkan popularitas di media sosial.

2) Media sosial memberikan kesempatan untuk berinteraksi lebih dekat dengan konsumen. Media sosial menawarkan bentuk komunikasi yang lebih individual. Melalui media sosial para pemasar dapat mengetahui kebiasaan konsumen mereka dan melakukan interaksi secara personal serta membangun keterikatan yang lebih dalam.

Abdullah (2012: 32) menyatakan jika sebuah merek/produk akan diluncurkan, maka media sosial digunakan untuk menyebarkan informasi yang sifatnya membuat teman atau pengikutnya menjadi penasaran. ekarang ini banyak situs-situs yang melakukan penjualan barang dan jasa lewat media sosial, salah satunya adalah menggunakan Instagram. Instagram menjadi sosial media yangbanyak sekali peluang untuk berbisnis para penggunanya. Bisa dimanfaatkan sebagai media komunikasi pemasaran, melalui share foto-foto produk penjual, dan memiliki banyak follower Instagram memudahkan untuk konsumen melihat produk yang di jual dan dapat langsung memberi komentar dibawah foto yang diminati.

Antony Mayfield (2008: 05) dalam Siti Nurjanah (2014) menyatakan indikator dari sebuah social media yaitu :

1. Partisipasi.

Media sosial mendorong kontribusi dan umpan balik (feedback) dari setiap orang yang tertarik. 
2. Keterbukaan.

Hampir semua pelayan social media terbuka untuk umpan balik (feed back) dan partisipasi. Mendorong untuk melakukan pemilihan, berkomentar, dan berbagi informasi.

3. Percakapan.

Komunikasi yang terjalin antara dua arah, dan dapat didistribusikan ke khalayak tentunya melalui social media tersebut.

4. Komunikasi.

Social media memberi peluang komunitas terbentuk dengan cepat dan berkomunikasi secara efektif. Komunitas saling berbagi minat yang sama, misalnya fotografi, isu-isu politik atau program televisi dan radio favorit.

5. Saling Terhubung.

Hampir semua social media berhasil pada saling keterhubung, membuat link pada situs-situs, sumber sumber lain dan orang-orang.

6. Keterampilan siswa menggunakan media sosial.

Sosial media memberikan terobosan untuk merubah pola pikir dilingkungan mahasiswa fakultas ekonomi universitas muhammadiyah sidoarjo untuk berwirausaha bisa memperkecil resiko untuk gagal dan mempermudah untuk memasarkan produk lebih luas tanpa biaya yang sangat tinggi. Untuk menjadi wirausaha yang sukses mahasiswa harus bisa memperluas jaringan yang luas untuk lebih berkomunikasi dengan yang lain (Herwaman Kartajaya, 2008) dengan cara menggunakan internet. Dikarenakan peran sosial media semakin diakui dalam mendongkrak kinerja dalam dunia bisnis. Efektivitas pemanfaatan tergantung pada bagaimana pemilik merek menggunakannya seperti Samsung, Blackberry bahkan Apple adalah merek yang global dan sukses didorong oleh dahsyatnya media sosial.

Menurut Amstrong dan Kotler (2008) internet merupakan suatu jaringan komputer yang dipakai oleh umum, yang menghubungkan berbagai macam pengguna dari seluruh tempat di dunia ke pengguna lainnya dan menjadi tempat yang luas sebagai penyedia informasi. Perkembangan teknologi informasi di Indonesia selalu berjalan dari masa ke masa. Sebagai negara yang sedang berkembang, Indonesia selalu mengikuti berbagai teknologi informasi hingga akhirnya tiba di suatu masa di mana penggunaan internet mulai menjadi kebutuhan sehari-hari hampir seluruh kegiatan manusia.

Dalam melakukan bisnis online akan sangat membutuhkan konsep e-commerce dalam pemasaran akan produk yang akan dipasarkan. Menurut pendapat Schneider (2004) mendefinisikan e-commerce sebagai penggunaan transmisi data elektronik untuk mengimplementasi atau untuk meningkatkan nilai proses bisnis.

Selain itu, menurut Laudon (2004) ecommerce merupakan proses pembelian dan penjualan produk dan jasa secara elektronik, meliputi transaksi menggunakan internet, network, dan teknologi digital yang lain. Menurut Turban (2006) arti dari e-commerce sendiri adalah proses pembelian, penjualan, tranfer, atau penukaran produk, pelayanan dan atau melalui jaringan komputer, termasuk melalui internet. Dengan kata lain E-Commerce merupakan salah satu faktor pendorong untuk berwirausaha khususnya berbisnis online.

\section{Kewirausahaan}

Robert D. Hisrich, dkk (2017) mendefinisikan kewirausahaan sebagai suatu proses dinamis dalam menciptakan tambahan kekayaan. Kewirausahaan 
(adalah perilaku dinamis yang berani mengambil resiko serta kreatif dan berkembang. Menurut Suryana (2003) kewirausahaan adalah suatu proses dalam mengerjakan sesuatu yang baru (creative), dan sesuatu yang berbeda (inovative) yang bermanfaat memberi nilai lebih.

Program kewirausahaan dapat memberikan nilai manfaat yang besar dari konsep keilmuan, artinya secara langsung memotivasi civitas akademika melalui spirit kewirausahaan yang dipersepsikan dengan nilai-nilai yang terkandung di dalam kewirausahaan dapat membentuk cara berfikir kreatif, inovatif, dalam memotivasi kemandirian (Heri Erlangga, 2011: 122)

Makna program kewirausahaan bagi mahasiswa yang memperoleh mata kuliah kewirausahaan dirasakan sangat bermanfaat, dapat memberikan pemahaman tentang kemandirian dan kreativitas sehingga wawasan dalam kewirausahaan mereka dapatkan baik keilmuan dan praktis (Heri Erlangga, 2011: 119)

Beberapa pengetahuan yang harus dimiliki wirausaha diantaranya :

1. Pengetahuan mengenai usaha yang akan dirintis.

2. Pengetahuan peran dan tangung jawab.

3. Pengetahuan tentang manajemen dan organisasi bisnis.

\section{Kerangka Penelitian}

Minat berwirausaha adalah kemampuan untuk memberanikan diri dalam memenuhi kebutuhan hidup serta memecahkan permasalahan hidup, memajukan usaha untuk menciptakan usaha baru dengan kekuatan yang ada pada diri sendiri (Maman Suryaman, 2006: 22).

Adanya minat berwirausaha akan mendorong seseorang untuk berusaha mencari informasi-informasi yang terkait dengan kewirausahaan melalui media informasi dan bertanya pada orang lain yang mengerti tentang wirausaha untuk kemudian mencoba melakukan usahausaha wirausaha.

Seiring pertumbuhan seseorang khususnya seorang remaja akan timbul pada dirinya keinginan-keinginan baru. Tak terkecuali adanya rangsangan yang berkaitan dengan dunia usaha, akan mendorongya timbul minat untuk berwirausaha. Jiwa wirausaha adalah sifat dan gejala abstrak seperti pikiran, perasaan, dan angan-angan yang terjadi dalam diri seseorang untukmenciptakan nilai tambah dari keterbatasan, dengan menangkap peluang bisnis dan mengelola sumber daya melalui gagasan yang inovatif ke dalam dunia nyata secara kreatif.

Adanya respon terhadap apa yang dilihat, didengar, dan dicermati oleh seseorang pada suatu kondisi, maka hal ini akan menimbulkan kecenderungan hati serta memunculkan perasaan suka terhadap sesuatu. Kecenderungan hati dan perasaan suka merupakan bagian dari aspek psikologi seseorang, oleh karena itu minat berwirausaha yang mengiringi perubahan-perubahan pada pribadi seorang remaja inilah yang megindikasikan adanya pengaruh yang besar yang ditimbulkan oleh minat terhadap jiwa wirausahanya (Adha Rahmanul Ismail, 2014).

H1: Terdapat pengaruh variabel minat berwirausaha terhadap kewirausahaan.

Ada pengaruh yang positif dan signifikan antara penggunaan media sosial terhadap kreativitas berwirausaha Wonosobo (Prasetyo Wahyu Utomo, 2017). Media social merupakan sarana bagi konsumen untuk berbagi informasi teks, gambar, audio, dan video dengan satu 
sama lain dan dengan perusahaan dan sebaliknya (Philip Kotler dan Kevin Keller, 2012: 568). Peran media sosial semakin diakui dalam mendongkrak kinerja bisnis. Media sosial memungkinkan bisnis kecil dapat mengubah cara berkomunikasi dengan pelanggan, memasarkan produk dan jasa serta saling berinteraksi dengan pelanggan yang bertujuan untuk membangun hubungan yang baik. (JOM, 2016)

H2: Terdapat pengaruh penggunaan media sosial terhadap kewirausahaan.

Kerangka pengaruh minat berwirausaha dan penggunaan media soaial terhadap kewirausahaan,dapat digambarkan sebagai berikut:

Gambar 1

Kerangka Penelitian

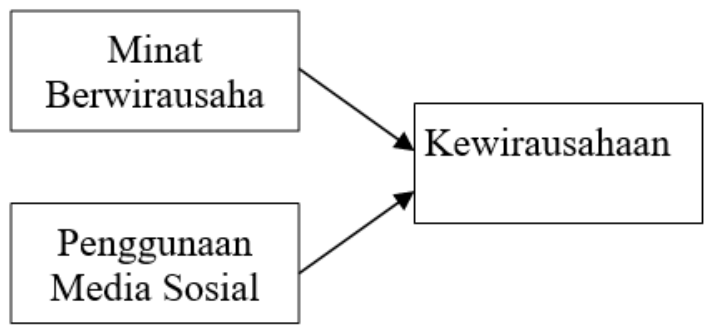

\section{METODE PENELITIAN Obyek Penelitian}

Penelitian dilakukan terhadap Mahasiswa STIE IPWIJA, semester Genap tahun ajaran 2017/2018. Penelitian dilakukan dalam kurun waktu tiga bulan yaitu dari Juni sampai dengan Agustus 2018.

\section{Desain Penelitian}

Jenis penelitian yang digunakan dalam penelitian ini adalah explanatory research tipe kausal yang berupaya menguji pengaruh variable independen terhadap variable dependen. Lingkup penelitian ini adalah menguji pengaruh Minat
Berwirausaha dan Penggunaan Sosial Media Terhadap Kewirausahaan. Terdapat 3 variabel penelitian yaitu, 2 variabel independen dan satu variabel dependen. Variabel independen yang pertama yaitu Minat Berwirausaha dengan simbol X1 dan variabel independen kedua yaitu Penggunaan Sosial Media dengan simbol X2. Satu variabel dependen yaitu Kewirausahaan dengan simbol Y. Kelayakan model penelitian ditunjukkan oleh nilai R Square dengan uji F (Sig. F). pengaruh antar variabel ditunjukkan oleh nilai koefisien regresi (b1 untuk koefisien regresi $\mathrm{X} 1$ terhadap $\mathrm{Y}$ dan $\mathrm{b} 2$ untuk koefisien regresi $\mathrm{X} 2$ terhadap $\mathrm{Y}$ ). Desain penelitian dan pengaruh variabel

independen terhadap variabel dependen pada penelitian ini adalah sebagai berikut: gambar 2

Desain Penelitian

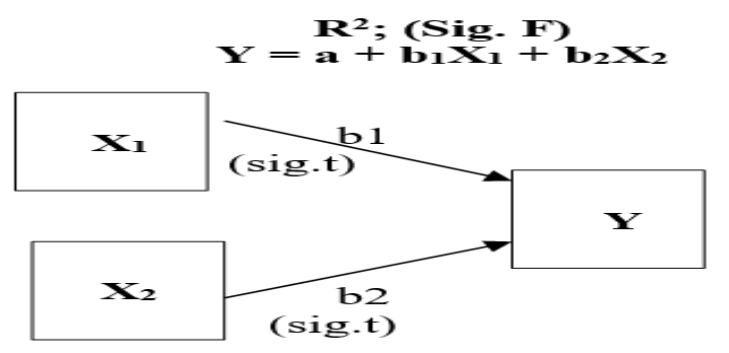

\section{Populasi dan Sampel Penelitian}

Pada penelitian ini yang menjadi populasi adalah seluruh Mahasiswa semester genap yang terdaftar sebagai mahasiswa yang melakukan perkuliahan dikampus Cikeas yaitu sebanyak 448 mahasiswa.

Sampel yang digunakan pada penelitian ini ditentukan menggunakan rumus Slovin (Mulyanto dan Wulandari, 2010: 103) yaitu sebanyak 84 orang. Adapun teknik pengambilan sampel menggunakan metode Simple Random Sampling, dimana responden peneliti merupakan mahasiswa yang terjangkau saat pengambilan data. 


\section{Definisi Operasional Dan Indikator Penelitian}

Operasional variabel dalam penelitian ini yaitu :

Table 1

Operasionalisasi Variabel

\begin{tabular}{|c|c|c|}
\hline Variabel/Konsep & Indikator & Skala \\
\hline $\begin{array}{l}\text { Minat berwirausaha adalah cara untuk } \\
\text { membangun, memiliki, dan menialankan usaha } \\
\text { (bisnis) agar dapat bermanfaat bagi diri sendiridan } \\
\text { orang lain(Saryanto, 2007:15) }\end{array}$ & $\begin{array}{l}\text { Berani mencoba } \\
\text { Pengelolaan waktu }\end{array}$ & $1-5$ \\
\hline $\begin{array}{l}\text { Pengounaan Sosial Media }\left(\mathrm{X}_{2}\right) \text { merupakan saranah } \\
\text { bagi konsumen untuk berbagi informasi teks. } \\
\text { gambar, audio, dan video dengan satu sama lain } \\
\text { dan dengan perusahaan dan sebaliknva } \\
\text { (Herwaman Kartajava, 2008) }\end{array}$ & $\begin{array}{l}\text { Partisipasi. } \\
\text { Keterbukaan } \\
\text { Komunikasi } \\
\text { Keterampilan }\end{array}$ & $1-5$ \\
\hline $\begin{array}{l}\text { Kerwirausahaan (Y) adalah perilaku dinamis yang } \\
\text { berani mengambil resiko serta kreatif dan } \\
\text { berkembang (Heri Erlangga: } 2012 \text { ) }\end{array}$ & $\begin{array}{l}\text { Kerja keras, Kerjasama, Penampilan, } \\
\text { Kevakinan, Pembuatan keputusan. } \\
\text { Pembelajaran, Ambisi }\end{array}$ & $1-5$ \\
\hline
\end{tabular}

\section{Metode Analisis}

Metode analisis yang digunakan adalah analisis deskriptif dan regresi linier ganda. Analisis deskriptif dilakukan untuk mendeskripsikan data penelitian. Analisis regresi linier ganda digunakan untuk menguji pengaruh beberapa variabel independen terhadap satu variabel dependen dengan tipe data metrik (Interval atau Rasio).

\section{Persyaratan Analisis}

Dalam penelitian ini peneliti menggunakan satu uji yaitu uji normalitas dengan menggunakan Analisis Kolmogorov-Smirnov (uji K-S).

\section{Analisis Koefisen Determinasi}

Analisis koefisien determinasi digunakan untuk menganalisis kemampuan variabel independen $\mathrm{X} 1$ dan $\mathrm{X} 2$ dalam menjelaskan variabilitas variabel $Y$ dalam model persamaan regresi yang dihasilkan dalam analisis. Hasil analisis berupa nilai koefisien determinasi $R$ Square (R2) yang menunjukkan berapa persentase kontribusi dari variable $\mathrm{X} 1$ dan X2 pada model dalam menjelaskan nilai dari variabel $Y$.

\section{Model Persamaan Regresi Linier Ganda}

Regresi ganda digunakan untuk meramalkan bagaimana keadaan (naik turunnya) variabel dependen (kriterium) bila dua atau lebih variabel independen sebagai faktor prediktor dimanipulasi (dinaik turunkan nilainya) (Sugiyono, 2005: 210). Persamaan regresi untuk dua prediktor adalah :

$$
\mathrm{Y}=\mathrm{a}+\mathrm{b} 1 \times 1+\mathrm{b} 2 \mathrm{X} 2
$$

\section{Uji Kelayakan Model}

Uji kelayakan model yaitu menganalisis kemampuan model persamaan regresi linier ganda dalam menjelaskan pengaruh Variabel Independen terhadap dependennya. Hipotesis statistik yang diajukan adalah sebagai berikut:

Ho $:=0:$ model tidak baik/tidak layak Ha : $\neq 0$ : model baik/layak

Pengujian hipotesis dilakukan dengan uji-F yaitu membandingkan nilai probabilitas (sig $F$ ) terhadap taraf uji penelitian $(\alpha=0.05)$. Kriteria yang digunakan untuk menguji hipotesis kedua penelitian adalah jika Sig F < a maka Ho ditolak dan Ha diterima, artinya model hasil penelitian layak digunakan untuk menjelaskan pengaruh $\mathrm{X} 1$ dan $\mathrm{X} 2$ terhadap Y.

\section{Pengujian Hipotesis}

Uji Hipotesis dalam penelitian menggunakan Uji t untuk menguji masingmasing variabel independen (minat berwirausaha dan penggunaan sosial media), sehingga dapat diketahui apakah masing-masing variabel independen berpengaruh terhadap variabel dependen (kewirausahaan). Kriteria pengujian hipotesis yaitu : 
- Hio : $b i=0$; tidak terdapat pengaruh

- Hia : bi $\neq 0$; terdapat pengaruh

Pengujian hipotesis dilakukan dengan uji-t yaitu membandingkan nilai probabilitas (sig $t$ ) terhadap taraf uji penelitian $(\alpha=0.05)$. Kriteria yang digunakan untuk menguji hipotesis penelitian adalah sebagai berikut:

- Jika nilai Sig $t<a$, maka H1o ditolak dan H1a diterima, artinya terdapat pengaruh $\mathrm{X} 1$ terhadap $\mathrm{Y}$.

- Jika nilai Sig $\mathrm{t}>\mathrm{a}$, maka H1o diterima dan H1a ditolak, artinya tidak terdapat pengaruh $\mathrm{X} 1$ terhadap $\mathrm{Y}$

\section{HASIL PENELITIAN DAN PEMBAHASAN \\ Hasil Penelitian \\ Koefisien Determinasi}

Nilai determinan memberikan gambaran seberapa besar kontribusi variabel independent terhadap variable dependen. Coefficient of Determination hasil pengolahan komputasi menghasilkan nilai :

Tabel. 2

Model Summaryb

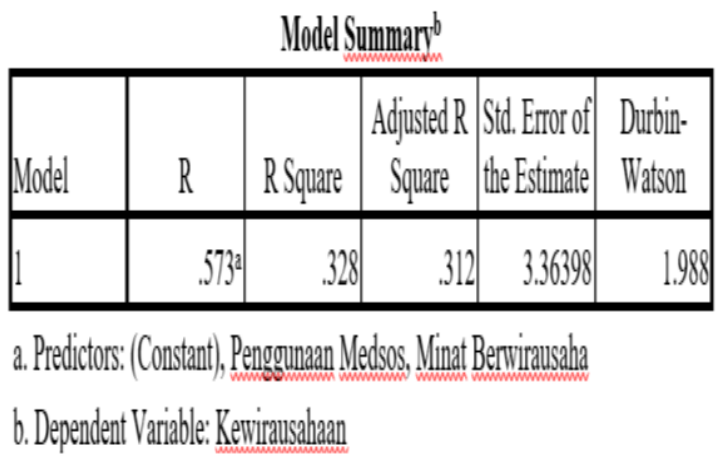

Sumber : Hasil penelitian yang diolah, 2018

Hasil analisis berupa nilai koefisien determinasi $R$ Square $\left(R^{2}\right)$ yang menunjukkan berapa persentase kontribusi dari variabel X1 dan X2 pada model dalam menjelaskan vriabilitas nilai dari variable Y. Berdasarkan data di atasdiperoleh hasil $\mathrm{Kd}=0,328 \times 100 \%=$
$32,8 \%$. Artinya dalam penelitian ini kontribusi yang diberikan X1 dan X2 sebesar $32,8 \%$.

\section{Model Persamaan Regresi Linear Ganda}

Hasil olah data komputasi untuk analisis regresi terlihat dalam tabel coefficient sebagai berikut :

Tabel. 3

Hasil Olah Data Regresi Ganda

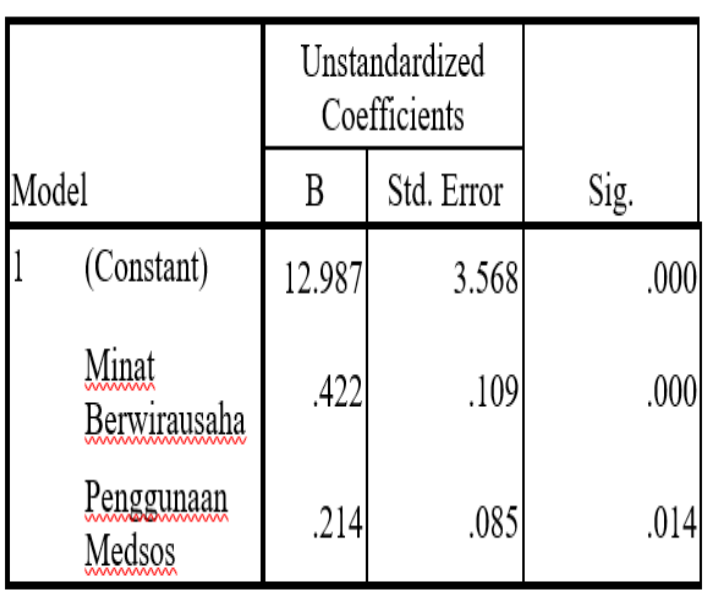

a. Dependent Variable: Kewirausahaan

Sumber : Hasil pengolahan data, 2018

Berdasarkan hasil analisis data dengan regresi ganda diperolah data sebagaimana tersaji di atas, sehingga persamaan regresi yang terbentuk dari hasil tersebut adalah :

$\mathrm{Y}=12.987+0,422 \mathrm{X} 1+0,214 \mathrm{X} 2$

Persamaan ini memberikan arti bahwa nilai variabel dependen kewirausahaan $(\mathrm{Y})$ dipengaruhi oleh ketiga variabel independen yaitu minat berwirausaha (), penggunaan media social (X ). Adapun makna dari nilai tersebut dapat diuraikan sebagai berikut :

1. Konstanta sebesar 12.987 artinya jika semua variabel independen dianggap konstan, maka variabel kewirausahaan mempunyai nilai sebesar 12.987 satuan.

2. Koefesien regresi variabel minat berwirausaha (X1) sebesar 0.422 menyatakan bahwa jika X2, artinya minat berwirausaha berpengaruh 
dengan arah positif terhadap kewirausahaan $(\mathrm{Y})$.

3. Koefesien regresi variabel penggunaan media sosial (X2) sebesar 0.214, artinya penggunaan media social berpengaruh dengan arah positif terhadap kewirausahaan $(\mathrm{Y})$.

\section{Uji Model}

Dari hasil analisis didapatkan nilai Fhitung sebesar 19.777 dengan nilai sig. 0,000 . Berdasarkan hasil tersebut didapatkan nilai sig. $0.000<0.05 \mathrm{Hal}$ ini berarti Ho tolak dan Ha diterima atau dapat diartikan bahwa model dikatakan layak.

\section{Pengujian Hipotesis}

Uji $t$ digunakan untuk mengetahui pengaruh dari masing - masing variabel secara individu, yaitu variabel minat berwirausaha dan variabel penggunaan medsos terhadap variabel kewirausahaan.

Tabel. 4

Koefesien Hasil Uji t

\begin{tabular}{|ll|r|r|}
\hline \multicolumn{1}{|c|}{ Model } & \multicolumn{1}{c|}{$\mathrm{t}$} & \multicolumn{1}{c|}{ Sig. } \\
\hline $1 \quad$ (Constant) & 3.640 & .000 \\
& & \\
& Minat Berwirausaha & 3.877 & .000 \\
& Penggunaan Medsos & 2.517 & .014 \\
\hline
\end{tabular}

a. Dependent Variable: Kewirausahaan

Sumber : Hasil pengolahan data, 2018

Nilai yang didapatkan dalam uji $\mathrm{t}$ untuk semua variabel independen tersebut memberikan nilai probabilitas sig. thit < 0.05 sehingga Ho ditolak dan Ha diterima.

1. Ada pengaruh yang signifikan variabel minat berwirausaha terhadap kewirausahaan pada Mahasiswa STIE IPWI Jakarta. Dibuktikan dengan hasil nilai sig $0.000<0.05$ artinya Ho ditolak dan Ha diterima.

2. Ada pengaruh yang signifikan variabel penggunaan media sosial terhadap kewirausahaan pada Mahasiswa STIE IPWI Jakarta. Dibuktikan dengan hasil nilai sig 0.014 $<0.05$ artinya Ho ditolak dan Ha diterima.

\section{Pembahasan}

Pengaruh Minat Berwirausaha Terhadap Kewirausahaan

Hasil analisis data dengan regresi hasil tersebut adalah : $\mathrm{Y}=12.987+0,422 \mathrm{X} 1+$ $0,214 \times 2$, sedangkan hasil uji hipotesis menujukkan Ada pengaruh yang signifikan variabel minat berwirausaha terhadap kewirausahaan pada Mahasiswa STIE IPWIJA. Berdasarkan hasil deskripsi data dan variabel kewirausahaan, dapat diketahui bahwa kewirausahaan pada mahasiswa STIE IPWIJA termasuk dalam kategori baik. Hal ini seharusnya memegang peranan yang tinggi dalam diri mahasiswa., dengan adanya minat berwirausaha diharapkan mahasiswa dapat terjun dalam dunia wirausaha. Hasil penelitian menunjukkan bahwa terdapat pengaruh positif dan signifikan minat berwirausaha terhadap kewirausahaan pada mahasiswa. Semakin tinggi kewirausahaana, maka semakin tinggi minat berwirausaha pada mahasiswa. Sebaliknya semakin rendah kewirausahaan, maka semakin rendah pula minat berwirausaha pada mahasiswa. Menurut Zimmerer, Scarborough dan Wilson (2008: 20), salah satu faktor pendorong pertumbuhan kewirausahaan disuatu negara terletak pada peranan sekolah atau pendidikan melalui penyelenggaraan pendidikan kewirausahaan. Kewirausahaan akan mendorong seseorang untuk memiliki pemahaman berwirausaha ini, seseorang 
akan memiliki minat berwirausaha. Pihak perguruan tinggi bertanggung jawab dalam mendidik dan memberi kemampuan wirausaha kepada para lulusannya dan memberikan motivasi untuk berani memilih berwirausaha sebagai karir mereka.

\section{Pengaruh Penggunaan Media Sosial Terhadap Kewirausahaan}

Hasil analisis data dengan regresi ganda diperolah data sebagaimana tersaji di atas, sehingga persamaan regresi yang terbentuk dari hasil tersebut adalah : $\mathrm{Y}=$ $12.987+0,422 X 1+0,214 X 2$. Pengujian hipotesis menujukkan ada pengaruh yang signifikan variabel penggunaan media sosial terhadap kewirausahaan pada Mahasiswa STIE IPWI Jakarta. Dibuktikan dengan hasil nilai sig $0.014<0.05$ artinya Ho ditolak dan Ha diterima. Maka semakin tinggi penggunaan media sosial semakin tinggi pula kewirausahaan bagi mahasiswa, sebaliknya apabila semakin rendah penggunaan media sosial semakin rendah pula kewirausahaan bagi mahsiswa. Hal ini disebabkan, sosial media dapat memainkan peran komunikasi. Karena menurut Morrisan (2007), merupakan upaya menjadikan seluruh kegiatan pemasaran atau promosi dapat menghasilkan citra atau image yang bersifat satu atau konsisten bagi mahawiswa. Sementara menurut Setiadi dalam Nugroho J (2003), pada tingkat dasar, komunikasi dapat menginformasikan dan membuat konsumen potensial menyadari atas keberadaan produk yang ditawarkan. Komunikasi dapat berusaha membujuk konsumen saat ini dan konsumen potensial agar berkeinginan masuk ke dalam hubungan pertukaran (exchange realationship).

\section{KESIMPULAN}

1. Ada pengaruh yang variabel minat berwirausaha terhadap kewirausahaan pada mahasiswa STIE IPWIJA.

2. ada pengaruh variabel penggunaan media sosial terhadap kewirausahaan pada mahasiswa STIE IPWIJA.

\section{SARAN}

1. Perlu adanya kegiatan yang berkelanjutkan untuk menjaga minat berwirausaha para mahasiswa sehingga bisa melahirkan mahasiswa yang menjadi wirausahawan.

2. Penggunaan sosial media perlu lebih diarahkan dan dimotivasi sehingga lebih terarah digunakan untuk berwirausaha. Hal ini dapat dilakukan dengan mengadakan pelatihan dan pilot project sehingga mahasiswa lebih punya skill dan contoh dalam penggunaan media social sebagai sarana berwirausaha.

3. Sebagai penelitian berikutnya, peneliti menyarankan agar perlu dilakukan kajian mendalam mengenai faktorfaktor apa saja yang dapat mempengaruhi kewirausahaan pada mahasiswa baik faktor internal dan faktor eksternal.

\section{DAFTAR PUSTAKA}

A. Khoerussalim Ikhs, Action! For One Family One Entrepreneur, (Jakarta: PT Elex Media Komputindo, 2013)

Alma, B. Kewirausahaan Untuk Mahasiswa dan Umum. Bandung: Alfabeta. 2011.

Belch, G. E., \& Belch, M. A., Advertising and Promotions: An Integrated Marketing 
Perspective. 7th edition. New York: McGraw-Hill. (2012)

Bygrave, W. D. The Portable MBA Entrepreneurship. Jakarta: Binarupa Aksara. 2003.

Ghozali, Imam. 2005. Aplikasi Analisis Multivariate dengan SPSS. Semarang: Badan Penerbit UNDIP.

Heri Erlangga, Semangat Kewirausahaan di Perguruan Tinggi (The Spirit Of Entrepreneurship), (Dinas Pendidikan Provinsi Banten, 2011)

Hermawan, Agus. Komunikasi Pemasaran. Jakarta: Erlangga. 2012.

Hilgard, E.R. \& Bowers, G. Theory of Learning: Century Psychology Series. New York: National Book Foundation. 2004.

Hisrich, R. D., et al. Entrepreneurship, Edisi 7. Jakarta: Salemba Empat. 2008.

Irham Fahmi, Kewirausahaan Teori, Kasus dan Solusi, (Bandung: ALFABETA, 2013)

Jackie Ambadar, dkk, Membentuk Karakter Pengusaha, (Bandung: Kaifa, 2010)

Kompasiana. Dampak Penggunaan Instagram. Diunduh dari http://www.kompasiana.dampak penggunaaninstagram.com pada tanggal 5 Desember 2016.

Kotler, Philip And Amstrong, Gary. Principle of Marketing. 7th Ed. New Jersey: Prentice. Hal.inc. 2010.

Laila Fitriani dan Asti Aini, "Pengaruh Strategi Pemasaran Terhadap Minat Nasabah Memilih Produk Tabunganku," Islamiconomics: Jurnal Ekonomi Keuangan dan Bisnis Islam, Vol.5, No.1, (Januari Juni, 2014),
Lambing, P. \& Kuehl. C. R. Entrepreneurship. 4th edition. Upper Saddle River: Prentice Hall. 2007.

Maman Suryaman. Minat Beriwausaha Pada Mahasiswa Pendidikan Teknik Elektro Fakultas Teknik Universitas Negeri Semarang. Skripsi. Tidak diterbitkan. UNNES. Diambil dari http://www.pustakaskripsi.com/o wnload.php? file=1856. 2013.

Mulyanto, H., dan Wulandari, A., 2010, Penelitian: Metode \& Analisis, CV Agung, Semarang

Morrisan. 2010. Periklanan : Komunikasi Pemasaran Terpadu. Jakarta : Ramdina Prakarsa

Nasrullah Rulli. Media Sosial Perspektif Komunikasi, Budaya, dan Sosioteknologi. Bandung: PT Remaja Rosdakarya. 2015.

Nugroho J. 2003, Perilaku Konsumen. Kencana. Jakarta

Rosmiati, Dony T \& Munawar, "Sikap, Motivasi, dan Minat Berwirausaha Mahasiswa", Jurnal Manajemen dan Keuangan, Vol.17, No. 1, (Maret, 2015)

Saryanto. Hubungan Antara Motivasi Kerja dan Minat Berwirausaha Terhadap Kesiapan Kerja SMK N 1 Cangkringan. Skripsi. Tidak diterbitkan. UNY (2008).

Sugiyono. 2005. Metode Penelitian Bisnis. Bandung: Alfabeta

Sulaksana, Uyung. Integrated Marketing Communications. Yogyakarta: Pustaka Pelajar. 2003.

Suryana. Kewirausahaan: Pedoman Praktis, Kiat dan Proses Menuju Sukses. Jakarta: Gramedia Sumber. 2003.

Thomas W Zimmerer, Norman $M$ Scarborough, Kewirausahaan 
dan Manajemen Usaha Kecil, Salemba empat

Turban, Efraim and David, King. Electronic Commerce. New Jersey: Amanogerial Perspective. 2006.
Zainuddin. S \& Sandi Pasakpangan, "Pengaruh Sistem Bagi Hasil dan Pendidikan Kewirausahaan Terhadap Minat Berwirausahaan Mahasiswa IAIN Palopo", Jurnal Muamalah, Vol. 5, No. 1, (April, 2015) 